\title{
The Demographic of Brontispa longissima variety of celebensis Gestro (Coleoptera: Chrysomelidae) on Mapanget Tall Coconut and Brown Dwarf Coconut
}

\author{
Novalisa Lumentut ${ }^{1,2^{*}}$, Sri Karindah ${ }^{3}$, Liliek Sulistyowati ${ }^{3}$ and \\ Retno Dyah Puspitarini ${ }^{3}$ \\ ${ }^{1}$ Post Graduate Programme, University of Brawijaya, Malang, Indonesia \\ ${ }^{2}$ Researcher at Indonesian Agency for Agricultural Research and Development (IAARD) \\ ${ }^{3}$ Faculty of Agriculture, University of Brawijaya, Malang, Indonesia
}

\begin{abstract}
Brontispa longissima variety of celebensisis considered an important pest on coconut trees. Basic information such as the biology and the life table of the species is extremely important in the effort to control its attack. The life table of B. longissima variety of celebensis on Mapanget Tall Coconut (MTC) and Brown Dwarf Coconut (BDC) can be examined in laboratory. The study aimed at examining the biology and the life table of $B$. longissima variety of celebensis on MTC and BDC. The study was conducted at Entomology Laboratory of Indonesia Palmae Research Institute, Manado, from June to November 2012. The parameters examined during the study consisted of the followings: 1) the development period from larvae of each instar into adult, 2) the longevity of adult, and 3) the number of eggs laid. The results of the study show that the young leaves of DMT are more suitable to support the life of B. longissima variety of celebensis compared to the young leaves of GRA, and this could be seen from the shorter immature development periods, the higher number of eggs laid, and the longevity of adult. B. longissima variety of celebensisis more suitable to live and grow on the young leaves of $D M T$ than on the young leaves of GRA. This could be seen from the average $r_{m}$ value which was higher on DMT leaves, that was 0.123 individual per adult per day, and mean generation time (T) which was 35.28 days, as compared to the $r_{m}$ value on GRA leaves, that was 0.108 individual per adult per day, and mean generation time (T) which was 39.61. The $r_{m}$ value shows the suitability of the host plants to increase the population of arthropods by considering the development periods, fecundity, longevity, survivorship, and sex ratio.
\end{abstract}

Keywords: life table, intrinsic rate of increase $\left(r_{m}\right)$, B. longissima, DMT, MTC

\section{Introduction}

Coconut (Coconut nucifera L.) is one of the most important commodities for farmers in Indonesia, especially those living at the central and eastern part of the country. At these regions, coconut trees become the main source of family income. The products derived from the plant are used to meet the domestic demands as well as to be exported to other countries helping to increase national foreign exchange. These products have contributed as much as $\$ 250$ million each year to the national revenue. Coconut indeed plays such important role to encourage the growth of new economic centers in the developing regions of Indonesia (Tarigans, 2004). There are 3.88 million hectares or $31.2 \%$ from the total areas used for second-class coconut cultivation in Indonesia, and $98 \%$ of it is in the form of smallholder farms spreading all across the country (Syakir, 2008).

One of the factors hindering the programs to improve the production of coconut in Indonesia is the attack of pests and plant diseases. One type of pests attacking the coconut trees is the coconut leaf beetles, $B$. longissima Gestro (Coleoptera: Chrysomelidae) (Tjoa, 1953; Kalshoven, 1981; Singh and Rethinam, 2005). Coconut leaf beetles are as native to Indonesia and Papua New Guinea. These beetles have long threatened the coconut industry both in Indonesia and internationally, since the pest has spread to Malaysia, Sri Lanka, Australia, Maldives, India, Myanmar, Bangladesh, Thailand, Vietnam and South China (Liebregts and Chapman, 2004; Liu et a.l, 2010) due to intensive transportation and weak regulation on quarantine of coconut and palm (Goles, 2003). In order to control the attack of this beetle, basic information such as biological information and life table of the arthropod is needed. The first step in studying an arthropod is by studying its demographic aspects. Demography is a quantitative analysis toward the characteristics of certain population, especially related to the growth patterns of the population, resilience, and population movement(Krebs, 1972; Price, 1984; Carey, 1993). According to Price (1997), a life table refers to summary of statements on the life of individuals in certain population or groups. Tarumingkeng (1992) asserts an additional statement that a life table can be used in calculating population statistic on population growth behaviors, which can give insight into important information such as birth, mortality, and breeding opportunities. The information then can be used as a reference in determining parameters of growth behavior. Life table information is systematic description of mortality and longevity of certain population. That kind of information is basic in comprehending density and 
increase or decrease in number of population (Price, 1997; Smith, 1990). A life table helps to choose the best and the most suitable ways in controlling pests by understanding the survivorship strategies of the pests. The study aimed at comparing biological parameters and life table parameters of B. longissima on MTC leaves and BDC leaves.

\begin{abstract}
II. Method
Augmentation of B. longissima variety of celebensis

The imagos of $B$. longissima variety of celebensis were collected from the coconut trees in Minahasa Regency, North Sulawesi Province. They were then grown and augmented at Entomology Laboratory of Indonesia Palmae Research Institute, Manado, from June to November 2012. The augmentation of B. longissima variety of celebensis were done in containers sized 30x10x6 cm. The beetles were fed on the leaves of MTC and BDC. The young leaves were changed with the new and fresh ones once in two days. This augmentation aimed at collecting uniform eggs, which were eggs laid by all female imagos at the same day. The second-generation arthropods were examined for their development, from eggs, first larval instars, second larval instars, third larval instars, fourth larval instars, fifth larval instars, pupae, female imagos, and male imagos.
\end{abstract}

\title{
The Effect of Coconut Varieties of MTC and BDC on the Development of B. longissima
}

Observation was done toward 130 eggs of $B$. longissima variety of celebensis. Each egg was put in different plastic containers, one container held one egg, and the containers were all labeled (date, variety, and number). The eggs were fed on the leaves of MTC and BDC. The young leaves were changed with the new and fresh ones once in two days. Examination was done every day from the time the eggs hatched until they turned into first larval instars, second larval instars, third larval instars, fourth larval instars, fifth larval instars, pupae, female imagos, and male imagos. The parameters to examine included sex and the number of imagos; the length of time needed for pre-oviposition, oviposition, and post-oviposition; and the number of eggs laid by female imagos. If male imagos died before the female did, new male imagos were taken as substitute. Data was tabulated on the life table using columns namely column $\mathrm{x}, \mathrm{l}_{\mathrm{x}}$, and $\mathrm{m}_{\mathrm{x}}$. The $\mathrm{x}$ column represented the age of adult, from their birth until their death. The $1_{x}$ column represented the survivorship of the female adult, and this was resulted from the division of the number of female adult at the age of $\mathrm{x}$ with the total number of adult at the beginning, while $m_{x}$ represented the number of eggs laid by each female adult multiplied with the sex ratio. The calculation of life table parameters was done using the following formula (Birch, 1948):

Net reproduction rate $\left(\mathrm{R}_{\mathrm{o}}\right): \mathrm{R}_{\mathrm{o}}=\sum 1 \mathrm{x} \cdot \mathrm{mx}$

Generation time (T)

$$
\begin{aligned}
& : \mathrm{T}=\frac{\ln R o}{r} \\
& : \mathrm{r}=\sum_{\mathrm{e}} \mathrm{e}^{-\mathrm{rx}} 1_{\mathrm{x}} \mathrm{m}_{\mathrm{x}}=1 \\
& : \lambda=\mathrm{e}^{\mathrm{r}}
\end{aligned}
$$

Finite rate of increase

Definite time $(\lambda)$

\section{Data Analysis}

Data was analysed using analysis of variance, and continued with contrast orthogonal analysis employing Minitab version 14.0. Data on survivorship as well as data on the number of eggs laid each day and sex ratio was used in making the life table lx and $\mathrm{mx}$ (lx: the ratio of female adult at age $\mathrm{x}$, and $\mathrm{mx}$ : the number of offspring produced by female adult at age $\mathrm{x}$ ). The curve of survivorship of female adult was made using Exel 2007 program.

\section{The biology of B. longissima variety of celebensis}

\section{Results And Discussion}

B. longissima variety of celebensis possesses has a holometabola metamorphosis type, which includes stages of egg, larva, pupa, and adult (Figure 1). The eggs of B. longissima are flat and brown, and are put in short chains consisting of two to five eggs on the young coconut leaves (Figure 1a). The first larval instars were white in color, and within 2-3 hours, the instars turned into yellowish color. The end of the abdomen of the first larval instar shaped like U-letter (Figure 1b). The size of eggs, larvae, and imagos of B. longissima variety of celebensisis presented in Table 1 . The results of the study show that differences in coconut varieties significantly affect the period for egg development and immature development of B. longissima variety of celebensis (Table 2). 


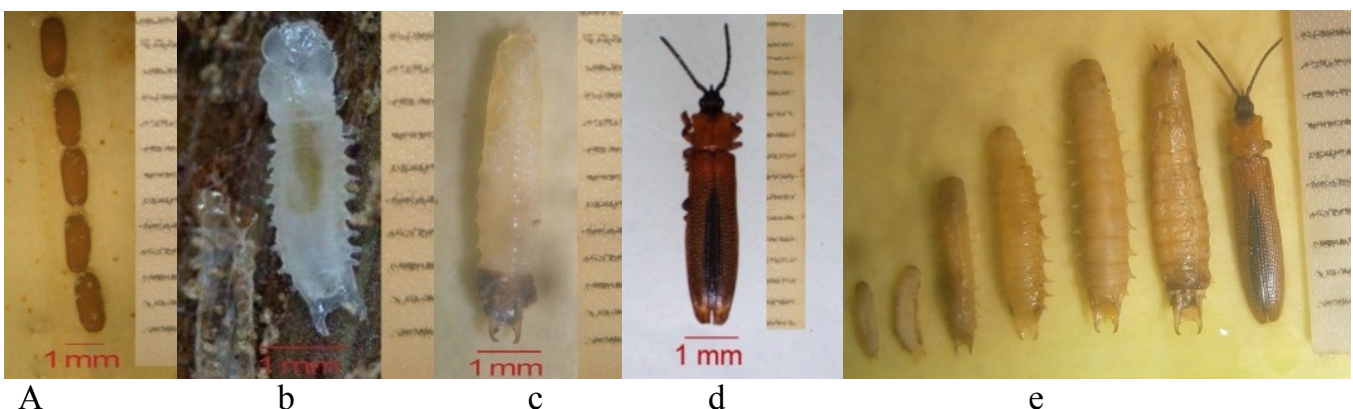

Figure 1. Development phases of B. Longissima variety of celebensis a: egg, b: larval, c: pupa, d: imago, e: first larval instar until adult.

$\underline{\text { Table 1.The size of the egg, larva, pupa and adult of B. longissima variety of celebensis }}$

\begin{tabular}{lcc}
\hline Development Phases & Length $(\mathrm{mm})$ & Width $(\mathrm{mm})$ \\
\cline { 2 - 3 } & $(\mathrm{x} \pm \mathrm{SD})$ & $(\mathrm{x} \pm \mathrm{SD})$ \\
\hline Egg & $1.37 \pm 0.08$ & $0.48 \pm 0.03$ \\
First larval instar & $1.80 \pm 0.24$ & $0.99 \pm 0.01$ \\
Second larval instar & $3.50 \pm 0.34$ & $1.30 \pm 0.02$ \\
Third larval instar & $5.01 \pm 0.39$ & $1.50 \pm 0.03$ \\
Fourth larval instar & $7.41 \pm 0.52$ & $1.76 \pm 0.07$ \\
Fifth larval instar & $9.5 \pm 0.50$ & $1.92 \pm 0.04$ \\
Pupa & $10.55 \pm 0.50$ & $1.95 \pm 0.04$ \\
Male adult & $11.04 \pm 0.34$ & $1.99 \pm 0.01$ \\
Female adult & $11.48 \pm 0.38$ & $2.0 \pm 0.00$ \\
\hline
\end{tabular}

Table 2.The Development of $B$. longissima variety of celebensison MTC and BDC

\begin{tabular}{lcc}
\hline \multirow{2}{*}{ Variable } & \multicolumn{2}{c}{ B. longissima variety of celebensison } \\
\cline { 2 - 3 } Egg & $5.23 \pm 0.76$ & BDC \\
First larval instar & $5.60 \pm 0.55$ & $6.62 \pm 0.59$ \\
Second larval instar & $5.56 \pm 0.49$ & $6.89 \pm 0.73$ \\
Third larval instar & $7.03 \pm 1.0$ & $7.08 \pm 0.73$ \\
Fourth larval instar & $9.52 \pm 1.36$ & $8.01 \pm 0.91$ \\
Fifth larval instar & $13.03 \pm 1.49$ & $10.86 \pm 2.01$ \\
Pupa & $6.60 \pm 0.49$ & $14.07 \pm 1.94$ \\
Life cycle & $52.57 \pm 2.75$ & $6.97 \pm 0.70$ \\
\hline
\end{tabular}

The results of the study show that differences in coconut varieties significantly affect the period for egg development and immature development of B. longissima variety of celebensis. The development phases of eggs, larvae, pupae, and adult were shorter on MTC variety than on BDC variety. The eggs of $B$. longissima veriety of celebensis on MTC developed in a shorter period on than those on BDC, which were 5-6 days on MTC and 6-7 days on BDC. This result is in line with the results of the study by Waterhouse and Norris (1987). This means that BDC variety is more suitable for the growth and development of B. longissima variety of celebensis, as compared to MTC variety. The oviposition period, the longevity of both male and female imagos, and the number of eggs laid on BDC variety are longer than those on MTC variety (Table 3). Life cycle as well as development period until the formation of adult on MTC variety is shorter than on BDC variety.

Data on survivorship or the chance of life for B. longissima variety of celebensis was collected from the daily observation since egg phase into adult phase that was arranged in a life table. Based on the life table, the survivorship curve $\left(1_{x}\right)$ and the fecundity of female adult $\left(\mathrm{m}_{\mathrm{x}}\right)$ could be found out. The survivorship curve $\left(1_{\mathrm{x}}\right)$ of B. longissima variety of celebensis on both MTC and BDC leaves is presented in Figure 2.

The survivorship of female adult of $B$. longissima variety of celebensis seemed to decrease when they were 41-day old on MTC and 36-day old on BDC. The survivorship of B. longissima variety of celebensis on $\mathrm{BDC}$ variety was found to be lower than the survivorship of $B$. longissima variety of celebensis on MTC. This means that death of $B$. Longissima variety of celebensis happens faster on BDC variety than on DMT variety. 
The survivorship curve of B. longissima variety of celebensis shows Type I Pattern, in which death mostly happens to adult or those at the end of the development phase.

Table 3.Pre-oviposition, Oviposition, Post-oviposition, and length of life of adult of $B$. Longissima variety of celebensis on MTC and BDC leaves

\begin{tabular}{lcc}
\hline \multirow{2}{*}{ Variable } & \multicolumn{2}{c}{ B. longissimavariety ofcelebensison } \\
\cline { 2 - 3 } & MTC & BDC \\
\hline Pre-oviposition period & $13.97 \pm 2.68$ & $20.28 \pm 2.6$ \\
Oviposition period & $46.1 \pm 11.1$ & $36.44 \pm 7.22$ \\
Post-oviposition period & $30.58 \pm 5.05$ & $29.77 \pm 7.59$ \\
Length of life for female adult & $90.6 \pm 12.2$ & $86.49 \pm 9.74$ \\
Length of life for male adult & $87.0 \pm 12.5$ & $82.24 \pm 9.65$ \\
Number of eggs laid (female/number) & $76.0 \pm 23.7$ & $58.5 \pm 18.4$ \\
Sex ratio $(\lesssim: q)$ & $1 ; 1.14$ & $1 ; 1.04$ \\
\hline
\end{tabular}

MTC variety was more suitable to become the host for $B$. longissima variety of celebensis based on the number of offspring per day $\left(\mathrm{m}_{\mathrm{x}}\right)$ (Figure3). The value of $\mathrm{m}_{\mathrm{x}}$ showed that the number of female offspring produced by the female adult of B. longissima variety of celebensis on MTC was higher than on BDC. The highest value of $\mathrm{m}_{\mathrm{x}}$ happened on day 12 for MTC and day 21 for BDC. This means that the young leaves of MTC is more suitable for the growth and development of $B$. longissima variety of celebensis than the young leaves of BDC.

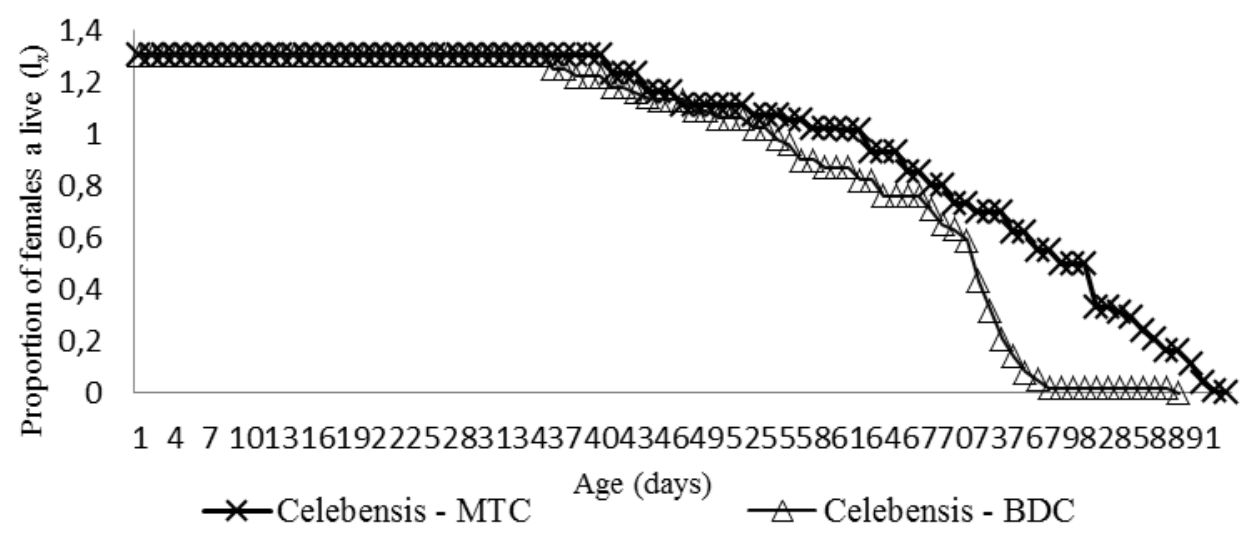

Figure 2.The survivorship of $B$. longissima variety of celebensis on BDC and MTC

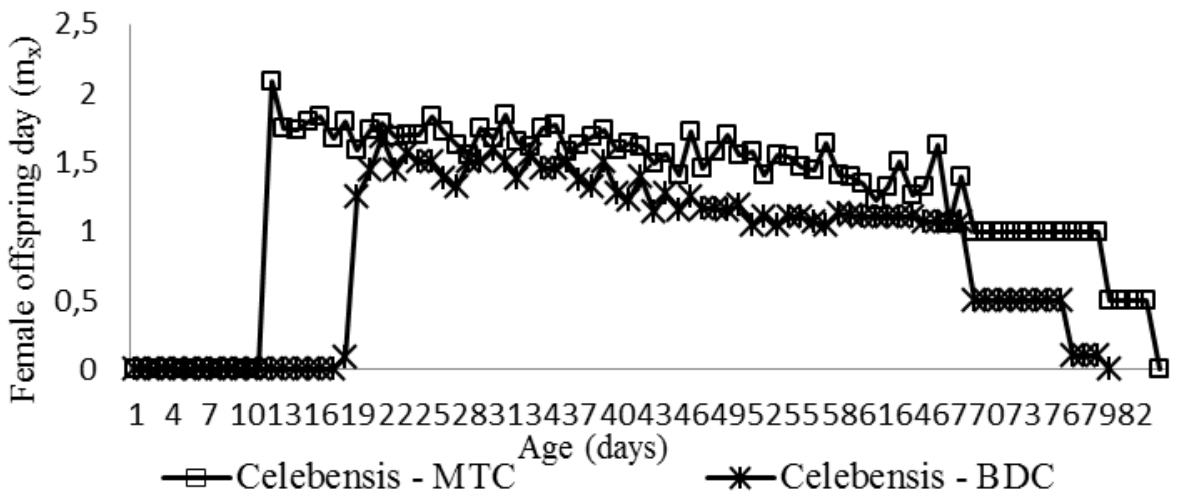

Figure 3.The number of offspring per day $\left(\mathrm{m}_{\mathrm{x}}\right)$ produced by adult female adult based on age on MTC and BCD variety

The life table of B. longissima variety of celebensis on MTC and DBC consists of net reproduction rate $\left(\mathrm{R}_{\mathrm{o}}\right)$, intrinsic rate of increase $\left(\mathrm{r}_{\mathrm{m}}\right)$, finite rate of increase (a) and mean time generation $(\mathrm{T})$ calculated based on survivorship $\left(l_{\mathrm{x}}\right)$ and daily fecundity $\left(\mathrm{m}_{\mathrm{x}}\right)$. The results of the calculation is presented in Table 4 . The value of $R_{0}$ shows the multiple numbers of populations on each generation (Birch, 1948). The value of $\mathrm{R}_{0} B$. longissima variety of celebensis was higher on MTC than on BDC. Thus, it means that in one generation, the multiple of the four varieties of $B$. longissima variety of celebensis on MTC was 1.13 times higher than on BDC variety. If the value of $R_{0}<1$, this means that the population of the arthropod is going to extinction, whereas the value of $R_{0}>1$ 
means that the arthropod is increasing (Birch, 1948). The $\mathrm{R}_{\mathrm{o}}$ value of B. longissima variety of celebensis is $>1$, meaning that their number was increasing.

Table 4.Demographic Parameters of $B$. longissima variety of celebensis on MTC and BDC

\begin{tabular}{ccccc}
\hline \multirow{2}{*}{ Variety } & \multicolumn{4}{c}{ Parameter } \\
\cline { 2 - 5 } & $\mathrm{R}_{\mathrm{o}}$ & $\mathrm{r}_{\mathrm{m}}$ & $\mathrm{T}$ & $\mathrm{\lambda}$ \\
\hline Mapanget Tall Coconut & 76.67 & 0.123 & 35.28 & 1.13 \\
Brown Dwarf Coconut & 72.16 & 0.108 & 39.61 & 1.11 \\
\hline
\end{tabular}

Note: $\mathrm{R}_{\mathrm{o}}=$ net reproduction rate (individual/adult/generation), $\mathrm{r}_{\mathrm{m}}=$ intrinsic rate of increase (individu/adult/day), $\mathrm{i}=$ finite rate of increase (per day), $\mathrm{T}=$ mean time generation (day)

The value of $\mathrm{r}_{\mathrm{m}}$ shows the number of female offspring produced by female adult per day, and represents the multiple of population per day (Birch, 1948; Tarumingkeng, 1994). The $r_{\mathrm{m}}$ value was 0.123 per individual/adult/day on MTC variety, with the value of $\approx$ of 1.13 dayand $0.108 \mathrm{per}$ individual/adult/day on BDC variety, with the value of $:$ of 1.11 day. The multiple population of B. longissima variety of celebensis on MTC was 1.13 day, and was higher than on GRA, which was only 1.11 day. The difference in the value of $\mathrm{r}_{\mathrm{m}}$ was caused by the difference in the mortality, birth rate, and the development time of $B$. longissima variety of celebensis on MTC and BDC. The high $\mathrm{r}_{\mathrm{m}}$ value shows the suitability of the host plant to support the population of arthropods (Jin et at., 2012), by considering the development periods, survivorship, longevity, fecundity, and sex ratio (Carey, 1993).

Intrinsic rate of increase $\left(\mathrm{r}_{\mathrm{m}}\right)$ of a species cannot always be compared to the successful level of a species to live in a certain habitat. This simply is due to the selection process of the species that the $r_{m}$ value is relatively high so the species can compete with other species (Birch, 1948). Thus, in predicting the survivorship of arthropods, data on mean generation time (T) is needed. Generation time usually expresses the average age of breeding females within a population, which represents the time needed since eggs until the eggs hatch, become adult, and produce half of their offspring. The generation time of B. longissima variety of celebensis was shorter on MTC than on BDC. Birch (1948) states a species in a population having lower T value will grow faster than a species in a population having high T value. This means that MTC variety is more suitable for the growth and development of $B$. longissima variety of celebensis than BDC variety.

\section{Conclusion}

The young leaves of BDC are more suitable for the growth and development of B. longissima variety of celebensis than the young leaves of MTC, as shown from the shorter immature development period, higher number of eggs laid, and longer life of female adult. This can be seen from the higher $\mathrm{r}_{\mathrm{m}}$ value on MTC, that was 0.123 individual/adult/day, and the mean generation time $(\mathrm{T})$, which was 35.28 days, as compared to the $\mathrm{r}_{\mathrm{m}}$ value on BDC, which was 0.108 individual/adult/day, and mean generation time (T), which was 39.61 .

\section{Reference}

[1]. Birch, LC. 1948. The intristic rate of natural increase of an insect population. Journal Animal Ecology.hlm: 15-26

[2]. Carey,JR.1993. Applied demography for biologist with special emphasis on insect. New York: Oxford University Press. $\mathrm{p} 11-41$.

[3]. Goles, HG. 2003. Integrated Pest Management Practices for Mango. In anonim. 2003. Proceedlings, $34^{\text {th }}$ anniversary and annual scientific conference. Cebu, Pest management council of the Philippines Inc.

[4]. Jin, T, Yu-Yin Lin, Qi-An Jin, Bo Wen Hai and Zheng-qiangPeng., 2012. Age-Stage, Two-Sex Life Table of BrontispalongissimaGestro (Coleoptera: Chrysomelidae) Feeding On Four Plam Plant Varieties. J.Environmental Entomology 41(5):1208-1214.

[5]. Kalshoven, LGE. 1981. The Pest of Crops in Indonesia. Revised and translated into English by P.A. van der Lann. PT IchtiarBaru van Houve, Jakarta.701hlm.

[6]. Krebs, CJ. 1972. Ecology, the experimental analyses of distribution and abundance.HarperInternatl.Edition. Harper and row Publishers, new York, San Fransisco, London.

[7]. LiebregtsW, and Chapman K. 2004. Impact and Control of The Coconut hispine beetle, Brontispalongissima (Coleopteran: Chrysomelidae). Report of The Expert Consultation on Coconut beetle Outbreak in APPPC Member Countries. Bangkok, Thailand. 26-27 October 2004. 24-33 hlm.

[8]. Liu, YQ. YZ Chun, Y Liu, Y-L.Zhao.T-T.Liu. 2010. Evaluation against Brontispalongissima. Pesticide Biochemistry and Physology. Journal homepage : www. Elsevier.com/locate/pest. Di unduhpadatanggal 9 Oktober 2011.

[9]. Price, PW. 1984.Insect ecology. John Wiley and Sons, new York, Toronto, Singapore.

[10]. Price, PW. 1997. Insect ecology. Ed ke-3. Singapore: John Wiley and Sons, Inc.

[11]. Smith, RL. 1990. Ecology and Field Biology. $4^{\text {th }}$ ed. New York: harper Collins Publisher.

[12]. Singh. SP, Rethinam P. 2005. Coconut Leaf Beetle Brontispalongissima.APCC. Jakarta.

[13]. Syakir, M. 2008. Kebijakan penelitian dan pengembangan kelapa di Indonesia. Prosiding Seminar Regional PHT Kelapa di Manado. Puslitbangbun:1-10.

[14]. Tjoa Tjien Mo. 1953. Memberantas Hama-Hama Kelapadan Kopra. Noordhoff Klolff. Jakarta

[15]. Tarumingkeng, RC. 1992. Insektisida, Sifat, mekanisme Kerja dan Dampak Penggunaannya Ukrida, Jakarta.

[16]. Tarigans, DD. 2004. Sistem Usahatani Berbasis kelapa. Pusat Penelitian dan PengembanganPerkebunan. Diunduh dari internet http: //www.perkebunan.litbang.deptan.go.id. Pada tanggal 15 Maret 2011.

[17]. Waterhouse DF, Norris, KR. 1987. Biological Control, PacifikProspects.ACIAR.Incata Press. Melbourne. Australia 